\title{
Performance Analysis of Village-Owned Enterprises Based on Financial and Management Aspects in Blitar Regency, East Java
}

\author{
Tri Wahyu Nugroho* \\ Agricultral Socio-economic Department, Brawijaya University, Jl. Veteran, Malang, 65145, Indonesia \\ Received: 13 November 2019; Revised: 7 May 2020; Accepted: 14 July 2020
}

\begin{abstract}
This study aims to analyze the performance development of village-owned enterprises (BUMDes) as the manager of productive economic activities. Performance measurement based on financial aspects and management aspects. A financial aspect includes capital growth, asset growth, asset quality, profitability. While management aspects consist of BUMDes legality, constitution, and by laws, the secretariat office, facilities, operational executor, involvement of village government in the stewardship BUMDes, incentive/honorarium board BUMDes, financial reports, progress reports, accountability BUMDes, contributions BUMDes to Government village data analysis technique used in this study is an interactive model consist of three main things: data reduction, data presentation, and conclusion. The results were obtained (1) BUMDes Health category by 84 BUMDes or 38.2\%, (2) BUMDes category BUMDes Fit as many as 30 or $13.6 \%$, (3) BUMDes category Unhealthy much as 84 BUMDes or $38.2 \%$, (4) BUMDes category Off BUMDes as much as 22 or $10 \%$. This implies the need for follow-up of the Government to improve performance so that it can be BUMDes BUMDes the healthy category, especially for BUMDes inactive.
\end{abstract}

Keywords: performance; BUMDes; interactive model

\section{How to Cite:}

Nugroho, T. W. (2020). Performance Analysis of Village-Owned Enterprises Based on Financial and Management Aspects in Blitar Regency, East Java. HABITAT, 31(2), 64-77. https://doi.org/10.21776/ub.habitat.2020.031.2.8

\section{Introduction}

Government policies in encouraging and implementing village autonomy, among others, are shown by increasing opportunities for village governments to empower their potential, including in developing their economy or income. Law No. 06 of 2014 concerning Villages and Government Regulation Regarding the Implementation of Village Law No. 06 of 2014, it is an embodiment of the Government's inequitable development, especially in rural areas. In this case, the central Government's alignments in the economic development of the village. Various programs have been designed to enable villages to develop their economic potential so that they can be sources of village revenue. One source of village revenue that can be developed by the village government is by establishing a VillageOwned Enterprise (BUMDes) (Ridlwan, 2014).

*Corresponding Author.

E-mail : tw.nugroho@hotmail.com

Telp : +628113777347
BUMDes is a village economic institution/body that is incorporated and is owned by the village government, managed economically independently and professionally with capital wholly or primarily owned by a separated village government (Maulana, 2013). Current conditions indicate that the potential and enormous village assets have not been fully utilized optimally to encourage village economic growth (Sururi \& Mulyasih, 2017). This impact on the lack of capability and types of services to significantly improve the community's economy and in the context of encouraging and sustaining the fulfillment of village government needs, especially for increasing village original income ("Pendapatan Asli Desa : PADes") which so far have generally relied on village land ("tanah bengkok") (Ferdianto, 2016).

Village-Owned Enterprises (BUMDes) has goal economic development village-level (Sitepu, 2018). BUMDes does it based on the needs, potential, and capacity of the village, strengthening the village government's capital in the form of financing, village wealth. This can 
improve the economic level of rural communities. The basis for the establishment of the BUMDes was motivated by government and village community initiatives based on the principles of cooperative, participatory, and emancipatory from the community (Pebriyanti, 2020).

In line with the importance of BUMDes in the village economy development Blitar District Government cq. Blitar District Community and Village Empowerment Office have carried out BUMDes Institutional Development Evaluation in the form of Village Owned Enterprises (BUMDes) Performance Mapping as an effort to strengthen the potential of village economic institutions that already exist as business institutions engaged in the service sector/microfinance services, real sector activities both in self-management or partnerships and other businesses that are productive economic.

There have been many studies that study related to the performance of BUMDes; for example, (1) Dewi (2014) explains that giving the right legality to BUMDes can improve the performance of BUMDes in improving the village economy. (2) the results of research conducted by Anggraeni (2016) on the impact of the presence of BUMDes on the welfare of the community obtained the result that BUMDes has a significant benefit indirectly increasing community welfare. This study tries to analyze the development of BUMDes performance as a manager of productive economic businesses, including aspects of asset development towards initial capital, aspects of capital use, aspects of quality of productive assets, aspects of profitability, aspects of management.

\section{Research Method}

\subsection{Research Design}

Research methodology can be interpreted as a way of conducting an investigation or looking for facts that are carried out systematically and objectively. Nawawi (2001) argues that the method means a way that can be used to achieve the goal. Because the general purpose of the research is to solve a problem, the steps to be taken must be relevant to the problem that has been formulated. This chapter will describe some aspects of the research methods that will be used to achieve the objectives of this research. Some of these aspects, including among others: research methods, location and time of research, sampling techniques, research variables, types and sources of data, data collection techniques, and data analysis.

\subsection{Research Instruments and Data Collection Techniques}

The techniques applied in collecting data in this study, namely:

a. An in-depth interview (in-depth interview) is a way to get information by giving questions directly to respondents who can provide complete and comprehensive information related to research. Interviews were conducted with village-level stakeholders who were deliberately visited for meetings. The questions are developed based on the formulation of the problem.

b. Documentation is every written material in the form of essays, memos, announcements, instructions, magazines, bulletins, statements, rules of a community institution, and news broadcast to the mass media. From the description above, the documentation method is collecting data by examining essential records that are very carefully related to the object of research.

c. Literature review. Is a collection of reference books, articles, journals, research results that have relevance to the theoretical approach used in research. Some of the libraries used are related to BUMDes and village markets.

\subsection{Data analysis techniques}

Data analysis techniques depend on the type of data taken in the study. The type of data obtained in this study is primary data and secondary data. A census of all BUMDes was conducted to collect primary data, with a total of 220 BUMDes. Data collection is done by in-depth interviews and participatory observation and photos of activity phenomena. At the same time, secondary data obtained from documents related to this study include; village monographs, village maps or drawings, documentation, literature studies, previous research, and others.

This study's data analysis technique is an interactive model, as proposed by Miles and Huberman (1992). This model consists of three main things, namely data reduction, data presentation, and concluding. These three things intertwine with each other at the time, during, and after data collection is done to form an interactive cycle.

The context in this study indeed refers to data analysis techniques related to how social capital is formed, how social capital is maintained, and how social capital supports activities. The 
simple description of the concept of Miles and Huberman can be described as follows:

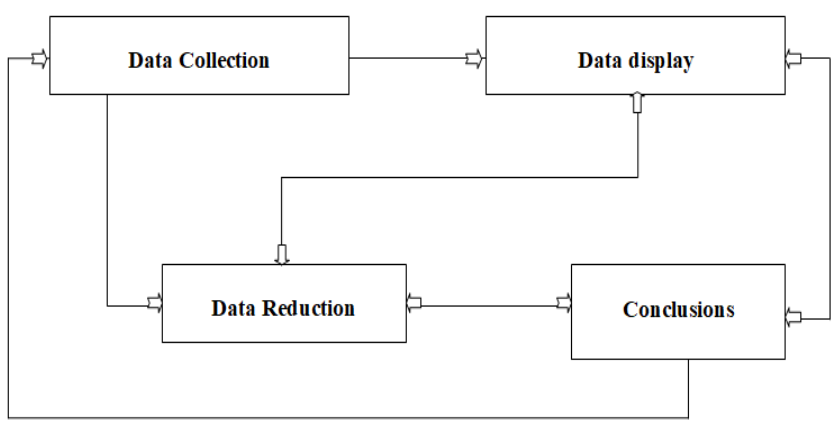

Figure 1. Interactive model in data analysis

The operationalization of the concept of data analysis techniques above in this study was carried out in the following stages:

a. Data Reduction

Data obtained from the field by the formulation of the existing problem examined relevant and irrelevant data after that. Found relevant data, immediately carried out data analysis through data reduction. Reducing data means summarizing, choosing the main points, focusing on the important things, looking for themes and patterns.

\section{b. Data Display}

After the data has been reduced, the next step is to present the data. In this research, the presentation of this data can be done in pictures, tables, flowcharts, pictures, and narrative descriptions.

\section{c. Conclusions Drawing Verification}

The third step in qualitative data analysis, according to Miles and Huberman (1991) is drawing conclusions and verification. The initial findings put forward are still temporary and will change if no substantial evidence is found to support the next data collection stage. But if the results put forward at an early stage, supported by valid and consistent evidence when the researcher returns to the field to collect data, then the conclusions put forward are credible.

The data collected is analyzed descriptively, that is, by describing (giving an indepth picture) the social phenomenon of tourism that occurs at the research location in the form of sentences or words and supported by tables and figures (Kustituanto \& Badrudin, 1994).

\subsection{Data Validity}

According to Moleong (2001); Hadi (2017). There are four kinds of criteria for the validity of the data: Trust (credibility), Transparency, Dependency, Comfinnability. In this study, using three types, among others:

a. Credibility

Data credibility is intended to prove the data collected by the actual, and several techniques to reach credibility are triangulation techniques, sources, checking members, an extension of the presence of researchers in the field, peer discussions, and checking the scope of references.

b. Dependability

This criterion is used to guard against the possibility of errors in collecting and interpreting data so that the data can be scientifically justified. Mistakes are often made humans error, especially researchers, because of limited experience, time, and knowledge. The way to determine that the research process can be accounted for is through audit dependability by a team of experts.

\section{c. Comfirmabifity}

This criterion is used to assess the results of research conducted by checking data and information and interpretation of research results supported by existing matrices in audit tracking. To avoid mistakes or errors in the data that has been collected, it is necessary to check the validity of the data. Triangulation is a data validity checking technique based on something outside of the data for monitoring purposes or compared to existing data. The process or triangulation technique used in this study compares the observational data with the interview data derived from interview guidelines, compared between observations in the field.

\section{Results and Discussions}

\subsection{Secondary and Primary Data Identification}

a. Secondary Data Identification

Secondary data identification is carried out by visiting the Blitar district Bapemas to obtain information in the form of data either hardcopy, softcopy, or data related to the Village-Owned Enterprises (BUMDes). The primary data collected in the Blitar district packaging bapemas is data in the form of BUMDes Blitar regency general data, which contains BUMDes management in Blitar regency.

\section{b. Primary Data Identification}

Primary data is the leading data obtained from the field. In this case, what is meant is BUMDes. Primary data identification starts from 
1 November until 30 November 2017. The primary data includes the completeness of performance mapping in BUMDes, which contains: (1) Identity of Village Owned Enterprises. (2) Capital (3) BUMDes Organization and Capital Structure (4) Real Sector Business Activities (5) Savings and Loan Business Management (6) Management, and (7) Financial Appendix (Balance Sheet).

Identification of primary data is carried out in the form of BUMDes performance mapping where from the 7 items above then an assessment is made into 5 aspects to determine the health level consisting of;

a. Capital Development Ratio Aspect

b. Distribution Aspect Ratio

c. Aspect Ratio of Earning Assets quality

d. Revenue to Cost Aspect Ratio and SHU to Asset Ratio

e. Management Aspect

From the 5 (five) aspects above, values are obtained according to the score weight, and the final results of the BUMDes category include:

$$
\begin{array}{ll}
\text { a. } & \text { Healthy }=>65 \\
\text { b. } & \text { Quite Healthy = 50,00 s/d 64,99 } \\
\text { c. } & \text { Unhealthy =0 s/d 49,99 } \\
\text { d. } & \text { Die (Not Active) = Neglected }
\end{array}
$$

BUMDes Performance Mapping is done by direct visit to BUMDes locations at the village level, preceded by a notification letter from the district government namely by Blitar District Bapemas that there is a mapping of BUMDes performance, then the mapping team descends to the location with instruments and then meets face to face with BUMDes management to get information by the instrument and to ask the management to show supporting evidence such as related documents and proof of activities carried out.

\subsection{Results of BUMDes Mapping in Blitar District}

\subsubsection{Financial Aspect}

\section{a. Capital Development}

The aspect of capital development is intended to look at the development of BUMDes capital by comparing current capital changes with an initial capital. The ratio of BUMDes Capital development in Blitar can be measured from the initial capital to the current total capital. The initial capital of BUMDes in the Blitar district is known by adding up the initial capital of each BUMDes at the time of its establishment. The total initial capital of BUMDes in Blitar Regency is Rp.
$3,353,876,624$ with an average of $\mathrm{Rp}$. $15,244,893.75$ each BUMDes. while the total capital at present is Rp.15,327,125,613 with an average of Rp. 69,668,752.79. There was an increase in the capital of Rp. 12,237,450,989 with an average of Rp. 55,624,777.22 or an increase of $364 \%$ of capital can be seen in the following figure.

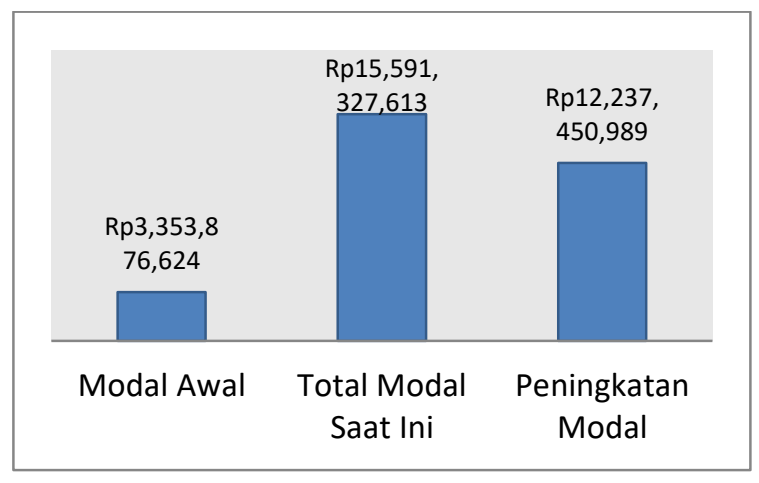

Figure 2. Aspect of Capital Development

This is influenced by several factors there are:

1) Additional capital each year comes from Village Fund Allocation (ADD) and Village Funds (DD) and other programs such as Jalin Matra PK2.

2) Increased capital from SHU allowance percentage

\section{b. Asset Developmnent}

The definition of assets is the value of all assets owned by BUMDes consisting of cash, funds in banks, receivables, funds invested, inventory, buildings or buildings, land, and others. The total initial assets of BUMDes in Blitar Regency amounted to Rp. 3,353,876,624, while the BUMDes assets are currently $\mathrm{Rp}$. $19,905,500,286$. an increase in assets of Rp. $16,551,623,662$ or an increase of $493 \%$ can be seen in the following figure.

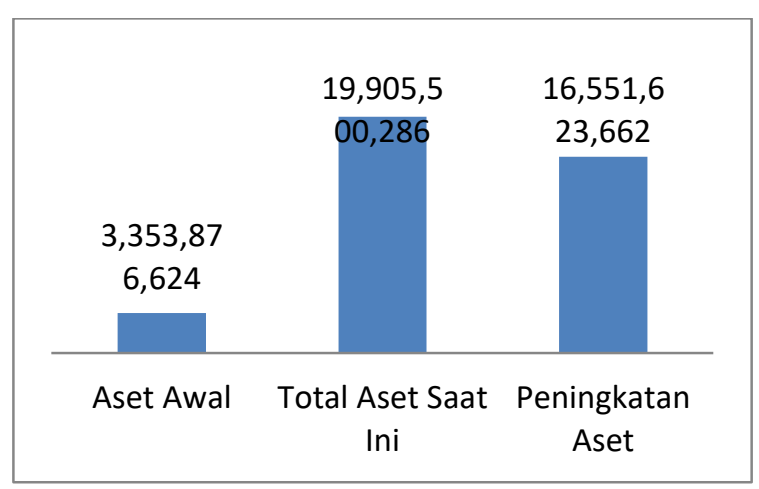

Figure 3. Asset Development Ratio 


\section{c. Distribution/utilization}

The aspect of distribution/utilization is comparing the amount of cash and money in the Bank with the amount of initial capital. The smaller the ratio, the better the utilization (use of capital). This ratio is to see the level of use of BUMDes capital for the business by comparing money that revolves as a capital with money that has not been used in cash and banks. The current BUMDes capital in Blitar Regency is Rp15,591,327,613, while the amount in cash and banks is Rp4,214,254,442. Funds that are used as business capital, not only savings and loans but also the real sector, are the difference of Rp11,377,073,171 or $72.9 \%$ can be seen in the following figure.

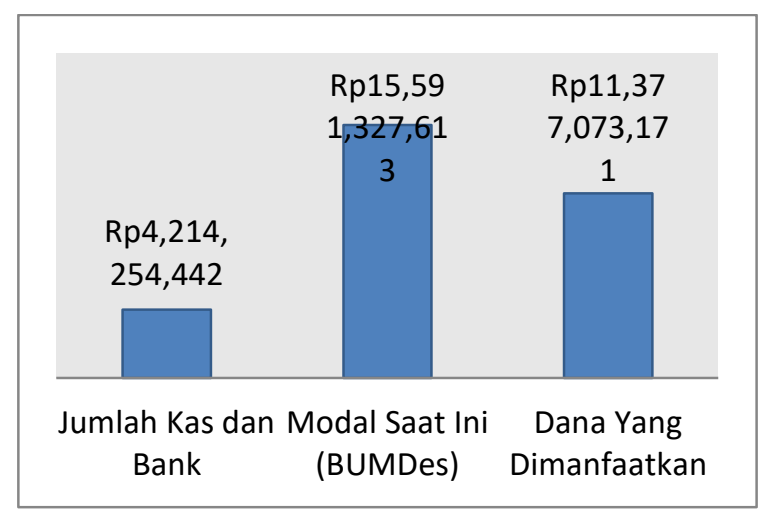

Figure 4. Utilization Capital Aspect

The use of BUMDes capital in Blitar is not yet maximal, and this is due to several factors including:

1) BUMDes does not have a thorough business planning.

2) BUMDes business management has not been maximized due to lack of knowledge and skills.

3) There is concern from the BUMDes management and the Government about the community's culture that the program funds are grants, so there is no obligation to repay or report so that BUMDes capital still settles in the account.

4) The use of a budget that is not by its purpose, namely for the construction of infrastructure or other forms outside the provisions of the BUMDes management rules.

\section{d. $\quad$ Earning Assets Quality}

The Earning Asset Quality Aspect is the number of bad business receivables/investment in the total business receivables/investment given. The smaller the accounts receivable / investment problem business, the more productive capital BUMDes used for business. The total receivables and investment of BUMDes businesses (savings and loans and the real sector) in the Blitar district is Rp14,020,581,251, while the amount of bad business receivables/investment is $\mathrm{Rp} 4,607,915,239$ or around $32.86 \%$ while accounts receivable/productive business investment amounting to Rp9,412,666,012 or $67.14 \%$ can be seen in the following figure.

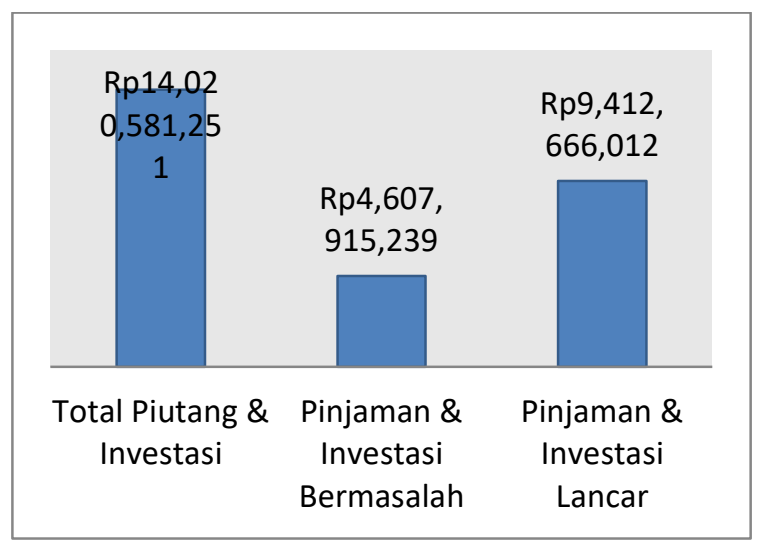

Figure 5. Earning Assets Quality Aspect

It shows that the receivables/investment of problem businesses in BUMDes in the Blitar Regency are still very high. It caused by several factors as follows:

1) The use of funds for consumptive

2) Failure

3) Unclear regulation for utilizing BUMDes capital

4) Corruption

5) Used for unproductive activities

6) The public perception that BUMDes business loan/investment funds are grants that do not need to be returned.

7) Bad BUMDes management business.

\section{e. Profitability}

1) Cost to Income Ratio

The profitability aspect is the comparison of costs to income, which is intended to determine the magnitude of operating expenses/costs compared to operating income in one financial year. The smaller the ratio, the more efficient BUMDes. If the total costs of all BUMDes in Blitar district in September 2017 are added up to $\mathrm{Rp} 1,141,497,335$, while the total revenue of all BUMDes in Blitar is Rp2,257,579,908. The ratio of cost to income ratio is $50.56 \%$. It shows that the management of BUMDes businesses in the Blitar district is still running quite efficiently because the 
ratio is $\leq 90 \%$. The ratio of cost to income can be seen in the following figure.

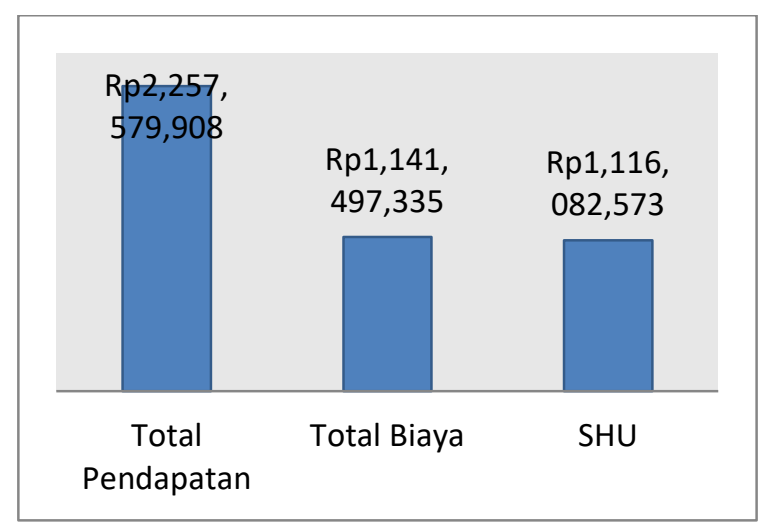

Figure 6. Cost to Income Ratio

\section{2) SHU to Total Asset Ratio}

An assessment of the ratio of SHU to total assets is included to measure the ability of BUMDes to obtain SHU from the total assets used. The total assets of all BUMDes in Blitar are Rp. 19,905,500,286, while the SHU obtained, was Rp. 1,116,082,573. The ratio of SHU to total assets is $5.6 \%$. The ratio of SHU to total assets can be seen in the following figure:

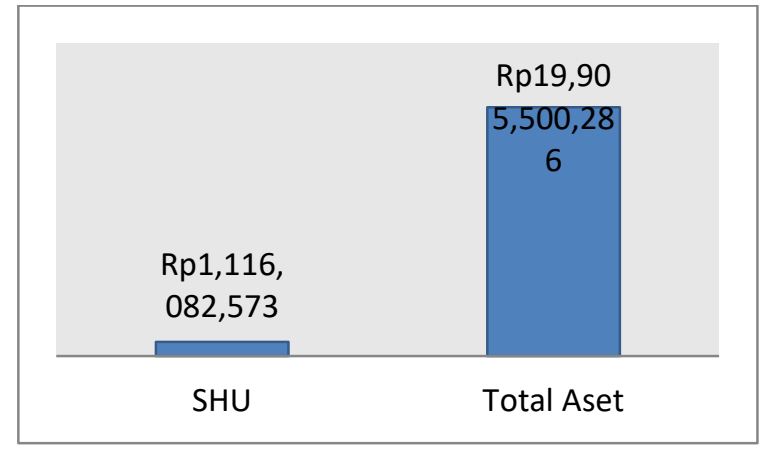

Figure 7. SHU to Total Asset Ratio

The ratio of SHU to assets is said to be good if the rate $\geq 10 \%$ so that when viewed from the percentage ratio below $10 \%$, the SHU obtained is still relatively low. Several factors influence the low SHU compared to the total assets used are as follows:

a. Most of the BUMDes business is Savings and Loans with high bad credit.

b. Many unproductive asset, consist of :

1) BUMDes capital is not used for business/frozen funds in banks/cash

2) Used to finance unproductive activities

3) Expenditures exceed the income earned

4) Lack of measurable business planning

\subsubsection{Management Aspect}

The management aspects used in this study consist of the legality of BUMDes, Statutes and bylaws, Secretariat Office, Facilities, Operational Implementers, Government Involvement in BUMDes Management, BUMDes Management Incentives/Honors, Financial Reports, Development Reports, BUMDes Accountability, BUMDes Contribution to the Government.

\section{a. BUMDes Legality}

BUMDes legality is a legal proof (validity) that must be owned by BUMDes. Based on Law Number 6 of 2014 concerning Villages Article 88 that BUMDes are formed through Village Deliberations while according to the PDTT Permendesa Number 4 of 2015 concerning the Establishment of Management and Disbursement and Disbanding of Village-Owned Enterprises Article 4 states that Establishment of BUMDes is based on Regulations/Perdes. Considering that BUMDes in Blitar Regency had been established since 2011 before the birth of Law, the establishment of BUMDes in Blitar District was registered with a notary to obtain legality as an institution. At the same time, the BUMDes management is determined by a Decree (SK) of the headman. The condition at the time of mapping BUMDes in Blitar District that can show ownership of 196 BUMDes Notary Deed, can prove ownership of Regulation 146 BUMDes and confirm ownership of SK Head of 144 BUMDes. The legality of BUMDes can be seen in the following figure.

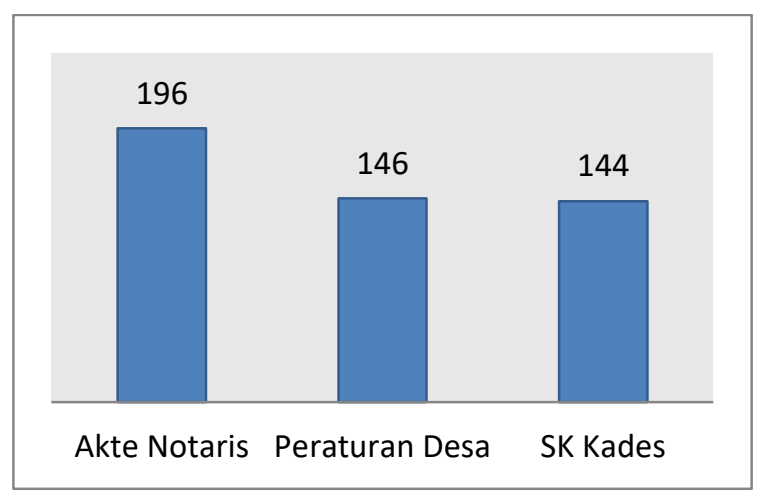

Figure 8. BUMDes Legality

Some BUMDes management at the time of mapping could not show the legality of BUMDes in the form of Notarial Deed, Perdes, and SK Kades as follows:

1) Lost Documentation.

2) The management felt that they had never received legality from the Government.

3) Hit by a fire accident. 


\section{b. Statutes and Bylaws}

Statues and bylaws (AD)-(ART) are two interrelated things, but not the same. Statues (AD) are a set of rules that discuss the organization's main ideas. Bylaws have a function as a complement or regulatory matters that have not been regulated in the Statues. Besides, ART also provides a more detailed and complete explanation of the main points that have been arranged in the statues.

Therefore, AD / ART has a significant meaning in strengthening the organization. AD / ART is a reference for the managers/managers of BUMDes organizations and in carrying out the tasks and authorities given.

Guidelines for compiling the statues and bylaws of Village Owned Enterprises (AD / ART BUMDes). In making and writing the BUMDes statues (AD) it must contain at least:

"Name, place of residence, period of establishment of BUMDes, foundation, principles and principles, intent and purpose, function and role of BUMDes, capital and type of business / business activity, duties, authority and prohibition of management, organizational structure of BUMDes management, and procedures for use and profit sharing from operations."

In making and writing, BUMDes Bylaws (ART) must at least contain: "Rights and obligations of management, service period, procedures for appointment and dismissal of management organization personnel, determination of business type, and source of capital. BUMDes conditions in Blitar Regency are based on the mapping results. It is known that 203 BUMDes have statutes, and 17 BUMDes do not have / cannot show the statutes. In comparison, BUMDes which have 201 bylaws and 19 BUMDes do not have Bylaws. Here is a list of ownership pictures of BUMDes AD / ART.

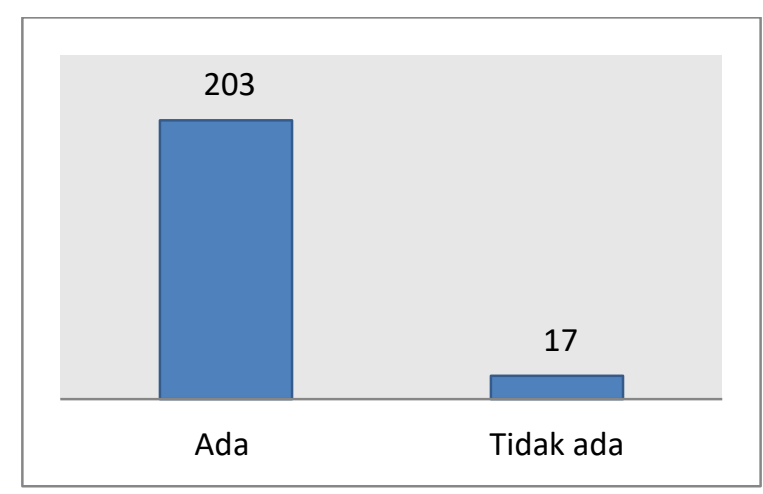

Figure 9. Ownership of Statutes

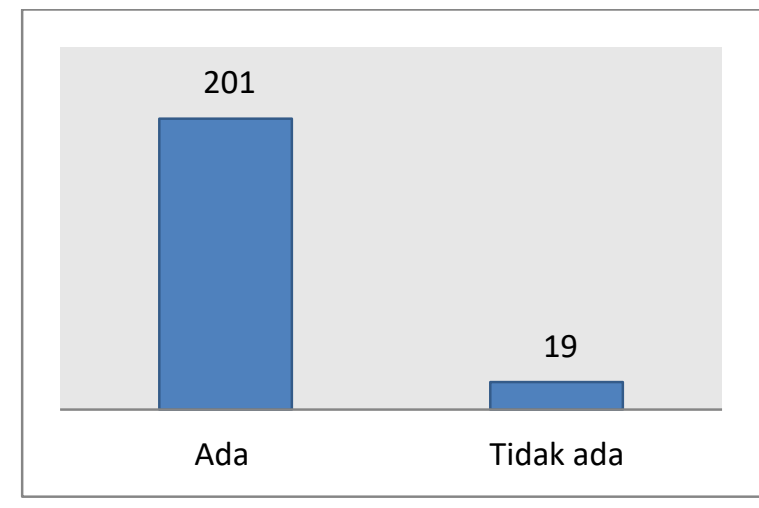

Figure 10. Ownership of Bylaws

\section{c. Secretariat Office / Secretariat Room}

BUMDes office/secretariat is a place to provide services, as well as a workspace. Besides, the office is also the identity of BUMDes management. Office function were :

\section{1) Receive Information}

The first function of the office is as a container used to receive and gather information. In practice, every related party interested in BUMDes will usually give/report any info related to BUMDes directly to the office.

\section{2) Provide Information}

The second function of the office is as a part that functions as a provider or disseminator of information. When BUMDes has developed and is managed by many personnel, access to information will be more difficult to spread. To overcome this, BUMDes makes the office as a container or central information that is valid and reliable.

\section{3) Asset Protector}

The third function of the office is as a place or container used to collect, store, and protect assets in the form of documents. As we know, BUMDes has a lot of essential files in the form of files and documents. These files and materials are not scattered everywhere and are easier to find; all of these files are usually stored in the office.

Given the importance of the BUMDes office/secretariat, BUMDes should have an office as a service center. BUMDes in Blitar Regency, which has a separate secretariat/office from the village office and the management house of 31 BUMDes, who have a joint secretariat (merging with the management house or village office) of 137 BUMDes while those who do not have 52 BUMDes have a secretariat/office. Pictures of BUMDes office/secretariat ownership can be seen below: 


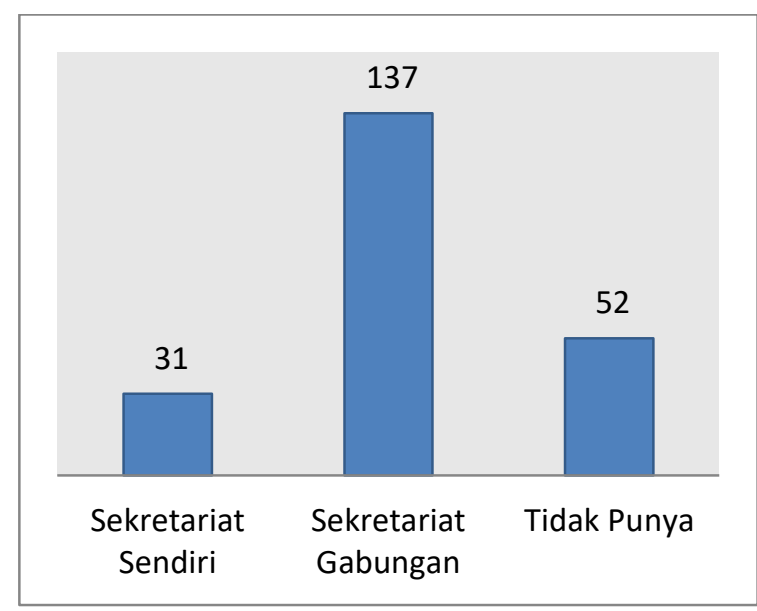

Figure 11. Ownership of Office/BUMDes Secretariat

\section{d. Signboard}

An institution, agency, or company that has an office in the form of a physical building must be equipped with a signboard. The definition of a signboard is a medium of information that contains the name of an institution, agency or company.

Signboar is an element that must be prioritized before other office supplies. Because with the signboard other people become more aware of where our office location. If other people know the location of our office, it will benefit because many people visit our office, especially if the office is a shop where people can increase sales turnover.

Besides being able to bring benefits by providing opportunities for prospective buyers to come to our store after seeing the signboard, here are some of the functions of the signboard:

\section{1) Identity}

The signboard functions as an identity, meaning that the signboard can show the profile name of an institution, agency, and company. A signboard is usually installed outside the office or in the reception room or lobby of an office.

\section{2) Guidance}

The function of the signboard as a hint is to provide information on where people will find the institution or company that they are looking for. With the signboard will make it easier for others to get directions to the place he is looking for.

\section{3) Advertising}

Nameplate also functions as a tool to advertise an institution, agency, or company. Advertising has one characteristic that is shown repeatedly. The function of the signboard as an advertising medium intended here is that if someone else sees the signboard of an institution, the name of the institution, agency or company will automatically become more and more sticky in everyone's mind, especially those who often pass by where the nameplate is attached.

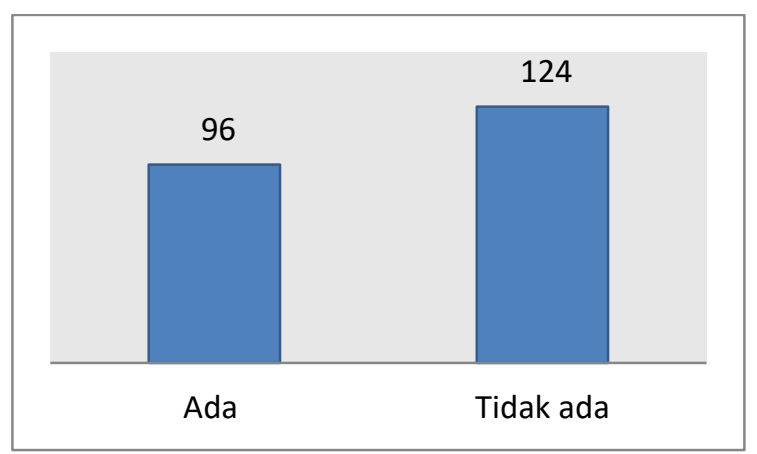

Figure 12. Signboard BUMDes Ownership

Although the BUMDes nameplate is very important for its function, the awareness of BUMDes management for installing nameplate is still very low. From the mapping of BUMDes throughout Blitar, the fact is that BUMDes that have 96 BUMDes or $43.6 \%$ have nameplates while 124 BUMDes or $66.4 \%$ do not have signboards.

\section{e. Stamp Ownership}

Seals have almost the same meaning as a stamp and seal, although there are differences in practice. A stamp/stamp is a symbolic form that represents the presence or presence of a person, official, or group.

The stamp functions as identification from the person whose name is listed or the signature is listed on the document. Even by name and trademark, someone's presence and approval can be known. But with a stamp, confidence in the agreement is getting stronger.

Suppose a signature in a contract. Signatures affixed by the parties to the agreement means that the parties have agreed to the contract, including agreeing with the contents.

From the mapping of BUMDes throughout Blitar, it is obtained that the BUMDes that have 159 BUMDes or $72.3 \%$ stamps while those who do not have a 61 BUMDes Stamp or $27.7 \%$. Pictures of BUMDes stamp ownership can be seen below: 


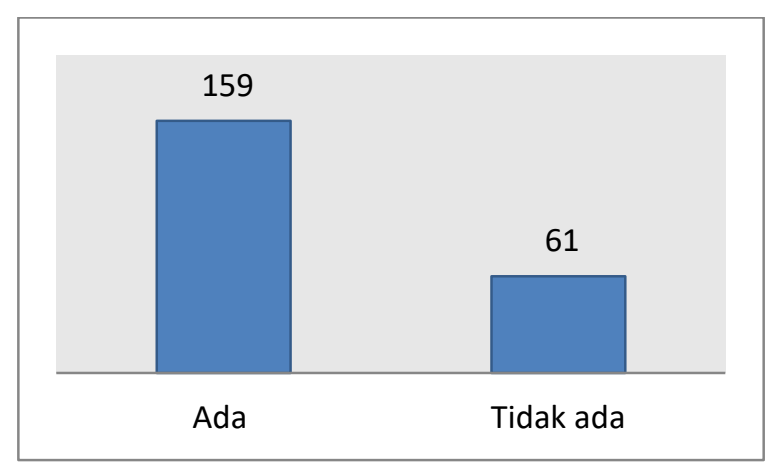

Figure 13. Stamp Ownership

\section{f. Operational Implementation}

The Structure of Village-Owned Enterprises (BUMDes) is one of the keys to the success of BUMDes as an institution. The concept of structure that has a clarity of duties and authority will determine the work process of this institution. But of course, it is also very much influenced by the personal qualifications of the people sitting there.

There are at least three of the most critical positions: Chairman or director, secretary, and treasurer. The function of the chairperson is very central because it is the captain who will lead the institution. Because BUMDes are closely related to business interests, a chairman must have a strong business vision while being able to carry out social consolidation or have the ability to approach the community.

The secretary functions not only to record the results of the meeting but also to make a draft of how the meeting results must be delegated to the relevant sections. The secretary also links the entire record of the company's performance process to a concept that is 'connected' to one another. So, the secretary is not just one of the meeting participants who only records the results of the meeting.

The treasurer function is very general, has responsibilities regarding the financial institutions. But unlike the treasurer's role in organizations such as "the RT arisan group", the BUMDes treasurer must have the ability to manage the money flowing into BUMDes large cash and then distribute it to various financial needs ranging from salaries, paying routine expenses to determine the amount of rupiah for business operational costs.

The treasurer function is essential in BUMDes because it functions as a financial manager who will manage the various revenue streams of the different business units that are run while determining the working capital for those businesses. It also must have the ability to read opportunities when BUMDes will carry out business development.

The BUMDes management must be people who have two abilities at the same time, capable of carrying out their duties and responsibilities according to their position, as well as having excellent communication skills in everyone in the village, starting from the government structure, business actors who are BUMDes partners to consumers of the business. BUMDes are trying their business.

The entire work system of this institution must be under overall supervision carried out by a supervisory team, which usually consists of three people. In addition to overseeing the running of the BUMDes work management system, the Supervisory Team also carries out supervising the organization of the organization from an external perspective. Usually, people who are in the structure of an institution or organization have difficulty assessing their performance.

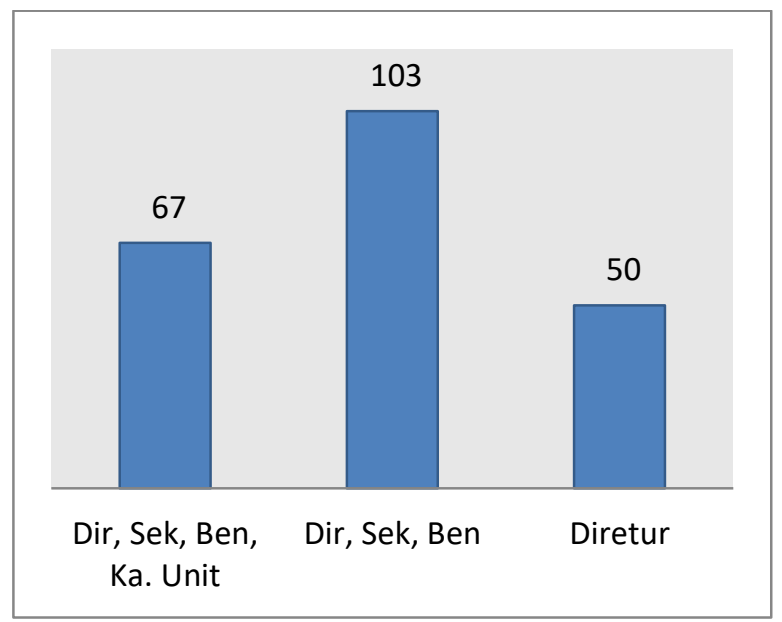

Figure 14. Operational Implementation

From the mapping of BUMDes throughout Blitar, the fact is that BUMDes which has a complete Organizational Structure of Directors / Chairpersons, Secretaries, Treasurers, Unit Heads totaling 67 BUMDes, which has Directors / Chairpersons, Secretaries, and Treasurers totals 103 while those only have Directors / The Chairperson alone amounts to 50 BUMDes.

\section{g. Involvement of Pemdes in Management of BUMDes}

Aside from being a function of the facilitator, the village government also provides information to the BUMDes management to deliver news about the development of regulations or news from the central Government which is 
expected to be implemented as soon as possible in BUMDes. Information provided to the village is expected to help improve the performance of BUMDes implementers in particular and village communities in particular to encourage their creativity towards the welfare of the community they expect.

Another function that is no less important than the village government is monitoring and evaluating the performance of Village-Owned Enterprises. The monitoring process is carried out on an ongoing basis so that it can properly monitor BUMDes activities. Evaluation is done quarterly or at any time if deemed necessary according to the provisions of the Statutes / By-Laws. In this monitoring and evaluation function, the government together with the board of commissioners, the advisory board (Village Head), and the community jointly supervise the running of BUMDes management and then together also report transparently and openly to the public through the ratification of reports BUMDes responsibility at the end of the period or at the end of each year.

According to the PDTT Permendes No. 4 of 2015 article 9 that BUMDes management organizations are separate from village government organizations. Therefore village officials/employees should not become BUMDes management. This is due to the function of the village government as a public servant to be separated from the function of BUMDes actors as an economic entity (business) aimed at obtaining profits.

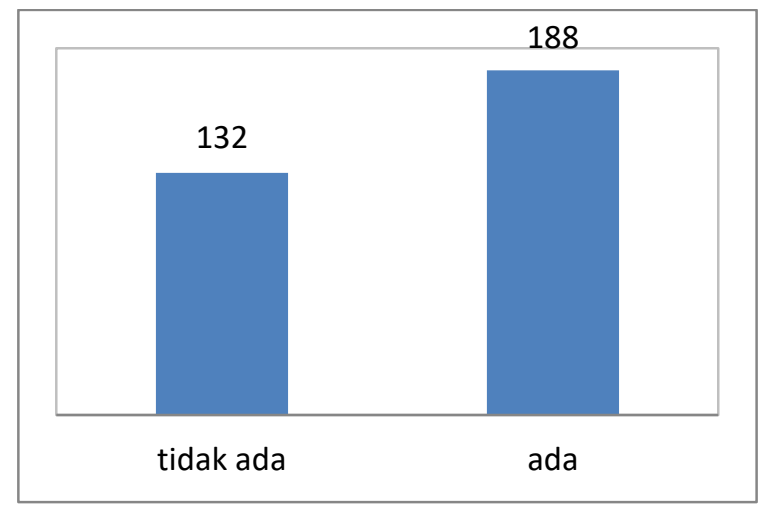

Figure 15. Involvement of Pemdes in Management of BUMDes

In the field, there are still many BUMDes administrators who come from village staff/employees, from 220 BUMDes in Blitar 88 88 BUMDes about $40 \%$ even involve village officials/employees as BUMDes administrators and 132 BUMDes or around $60 \%$ who already have administrators outside the equipment/ employees village. Involvement of Pemdes in Management of BUMDes can be seen in the figure 15.

This is due to several factors, among others:

1) Pada At the time of the establishment of BUMDes, the village government did not understand the management of BUMDes.

2) The Government had difficulty finding a human resource who was able to manage the BUMDes.

3) Community interest in becoming BUMDes management is low because the village government does not place BUMDes as an important indicator of village economic development.

\section{h. Incentive/Honorarium BUMDes Operator \\ BUMDes is projected as a business} institution that expands in terms of capital and business strength. It requires an award that is commensurate with the workload of all its employees. Giving a salary that is too small will result in less work productivity, affecting business development. But if the salary figure is considered too large, even though the BUMDes business is already large, it will be in the spotlight. These are some of the reasons that make young people still reluctant to join BUMDes, because BUMDes is deemed unable to be a business that can guarantee their future, one of which is difficult to get high income.

Some BUMDes that have been running in several regions show that they use the UMR standard as a benchmark. UMR is considered to be the most moderate in facing people's views. Interestingly, some BUMDes directors pay themselves low. But that is the chairman or director's attitude because he thinks more about serving and not looking for a living. But the most important thing is about productivity. The award for BUMDes management in the form of salary must support the perpetrators to be able to move productively to develop BUMDes businesses. Not only salary, BUMDes must also have a clear management concept and a surefire business strategy for that.

In Blitar district, there are still many BUMDes that have not given honorariums/incentives to their management either in the form of monthly or distribution from SHU. The mapping data in the field shows 137 BUMDes or $62.3 \%$ have not allocated 
honorarium/incentives to BUMDes management while those who received honorariums in the form of SHU 56 BUMDes $25.4 \%$ and those who received a monthly honorarium of 27 BUMDes or around $12.3 \%$ can be seen in the figure 16 :

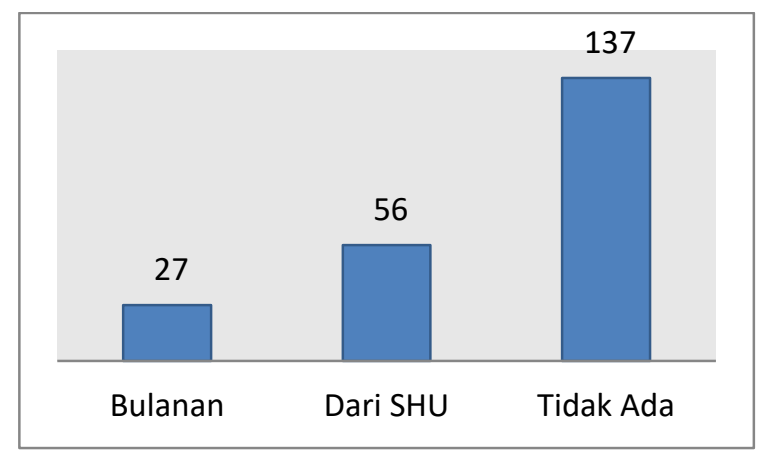

Figure 16. Operator Incentive Honorarium

The absence of incentives for the BUMDes management honorarium was caused among others:

1) Bad condition of BUMDes (unprofitable business).

2) There is an assumption in the BUMDes management that they are social workers for the village government so that they do not need to be paid.

3) BUMDes, which are still managed by village staff/employees allocate honorarium/incentives into one with village staff/village employees.

4) Do not know the salary mechanism of BUMDes management because they do not see the arrangement and the rule of law (perdes, AD / ART BUMDes) at the village level.

\section{i. Monthly Financial Reports}

As a business institution, Village-Owned Enterprises (BUMDes) must make honest and transparent financial reports. In addition to being a material for monitoring and evaluation, financial statements will also be a guideline for the steps to develop BUMDes.

In general, the BUMDes financial reporting system has similarities with other institutions, especially business institutions. BUMDes must record sequentially every transaction that comes in at once every expense made in an easy-tounderstand accounting system. Why should it be easy to understand because several parties will review this report. Second, a simple system can eliminate the possibility of financial engineering that will result in report manipulation. important:

Why is BUMDes financial reports so
1) The financial statements will inform every detail of the development of BUMDes as a business institution starting from the development of turnover, income/loss statements, and capital structure. A good report will make it easier for BUMDes to develop themselves into larger business institutions.

2) An excellent financial report will be anticipated if there is a turnover or a decline in selling power so that the management can immediately take steps before the BUMDes-owned business goes bankrupt.

3) To arrange materials inventory management, from this report it will be known how much stock of merchandise if the business is related to the product so that it can respond to the market well. The problem is, often, companies that feel their turnover increases forget about inventory management. As a result, their stock did not meet market needs. This can cause disappointment to consumers and harm turnover because consumers will choose another company to get the product they want, especially if the product is a typical village product and is not easily found in other villages or regions.

4) Financial statements are obviously very important to know for what BUMDes funds are used. Do not let the funds run out instead for unproductive activities.

BUMDes financial statements really should not be negligent. BUMDes is a village-owned business institution with government funds. This financial report will be the benchmark for those who are BUMDes supervisors to monitor BUMDes business development. Reporting that is not clear will be the door to open a case that can drag BUMDes to court.

Different from private business institutions. In a secluded area, the loss or failure of a business does not have a broad impact other than making its investors lose the investment. But in BUMDes, the failure of an effort must be clearly explained to ascertain the cause of the failure. If it turns out that the crash occurred due to an act of abuse of authority, the management must legally take responsibility legally.

Although BUMDes financial reports are critical, the fact is that in Blitar District, most of them have not made regular financial reports, namely 164 BUMDes or $74.5 \%$, have not made financial reports. In contrast, only 56 BUMDes 
$25.5 \%$ have made daily financial reports. This can be seen in the following image.

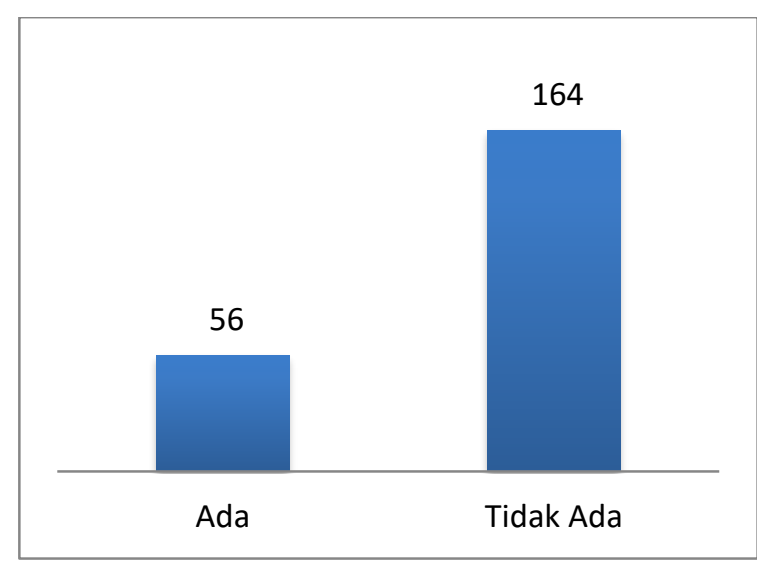

Figure 17. Monthly Financial Report

\section{j. $\quad$ Progress Report}

Village-Owned Business Entity (BUMDes) is a business entity whose entire or most of its capital is owned by the village through direct participation from village assets that are separated to manage service assets and other businesses for the maximum welfare of the village community. From this understanding, BUMDes has an obligation to provide BUMDes progress reports regularly to the village government. From the report, BUMDes advisors and supervisors can see a portrait of BUMDes updates, so they can be used as an evaluation material and as a reference for making village policies related to BUMDes.

The results of the field mapping in 220 BUMDes in 22 Subdistricts were obtained by BUMDes, who regularly reported to the village government of 25 BUMDes or $11.4 \%, 75$ BUMDes $34.1 \%$ did not routinely report and 120 BUMDes $54.5 \%$ had never reported to the Government. More can be seen in the following picture.

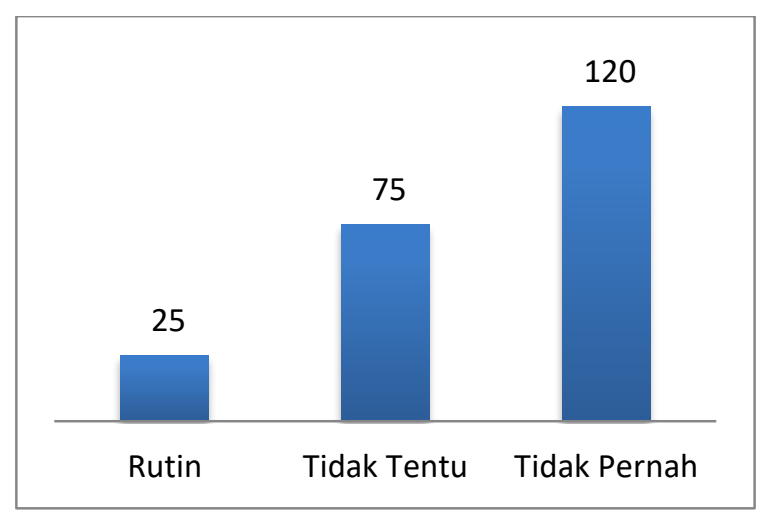

Figure 18. BUMDes Progress Report to Village

\section{k. BUMDes Liability}

Law No. 4 of 2015, which discusses the accountability of BUMDes management can be broken down into three stages, were:

1) The Operational Officer reports the accountability of the BUMDes implementation to the Advisor, who is exofficio held by the coordinator.

2) BPD supervises the performance of the Government in fostering the management of BUMDes.

3) The Government is responsible for the guidance of BUMDes to BPD, which is delivered through the Deliberation.

So that in the accountability of the implementation of BUMDes, there are three parties involved, namely Operational Implementers, Village Consultative Body (BPD), and Government. Finally, the accountability of the BUMDes implementation must be reported to the Government and BPD.

The data findings in the field in each BUMDes that carry out BUMDes accountability activities are 42 BUMDes or $19.1 \%$, while those that do not do 178 BUMDes or $80.9 \%$ can be seen in the following figure.

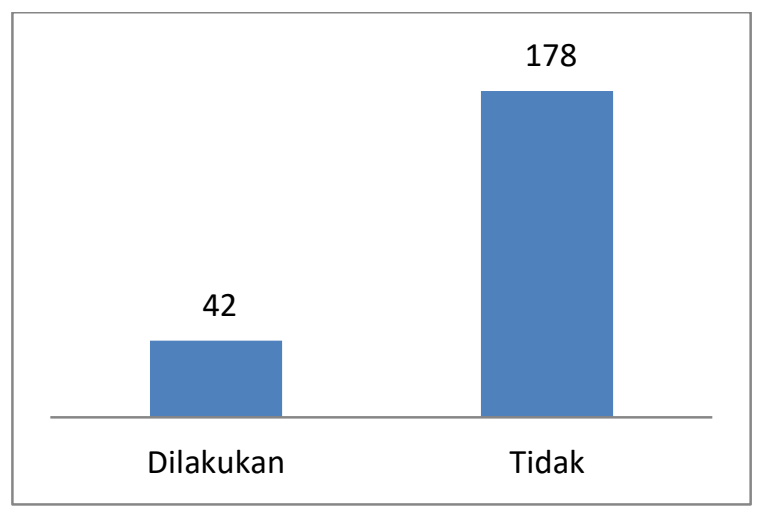

Figure 19. BUMDes Liability

\section{BUMDes Contribution to Government}

BUMDes was formed to manage village assets/potential to provide benefits to the community and Government. One of the benefits of BUMDes to the Government is the contribution income included in the APBDes. This is in line to establish BUMDes is to increase PADes. BUMDes in the Blitar Regency which have contributed to the increase in PADes by 36 BUMDes or $16.4 \%$ while 184 BUMDes or $83.6 \%$ have not contributed to the Government. More can be seen in Figure and Table Below. 


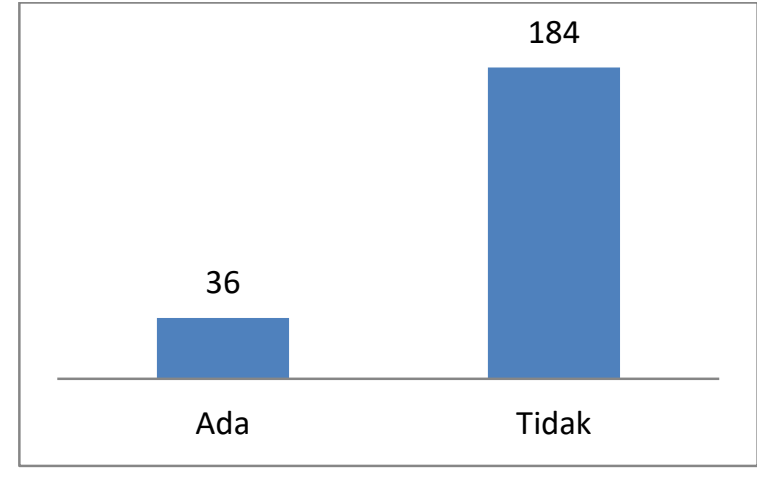

Figure 20. BUMDes Contribution to Pemdes

m. Determination of Health / Predicate

Determination of BUMDes health predicate depends on the results of the final evaluation both quantitatively by the results of calculations from the formula that has been set and qualitatively assessment, namely by the field assessment by the surveyor. Based on the calculation of the management aspects with a weight of $30 \%$ and financial aspects with a weight of $70 \%$, it can be made a predicate level of health as follows:

Table 1. Health Predicate

\begin{tabular}{|c|c|}
\hline SKOR & PREDIKAT \\
\hline No Management & UNACTIVE \\
\hline 0 until 49,99 & UNHEALTHY \\
\hline 50,00 until 64,99 & HELATHY ENOUGH \\
\hline 65,00 until 100 & HELATHY \\
\hline
\end{tabular}

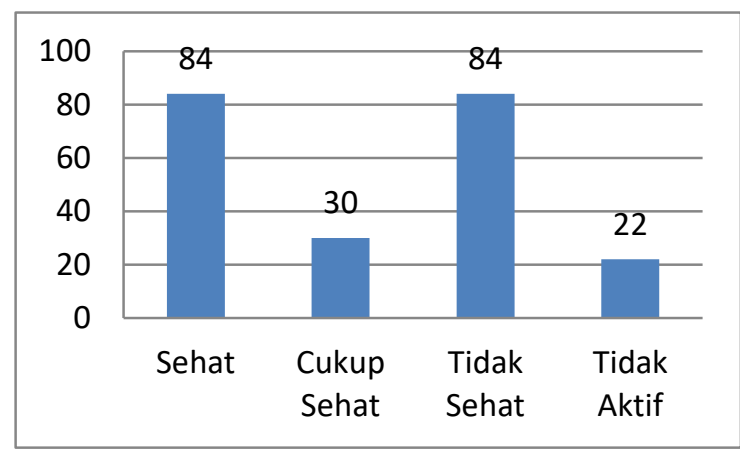

Figure 21. Percentage Diagram of BUM Desa

Health Levels in The Blitar Regency

From the results of the assessment of the health status of BUM Desa in the Blitar Regency which combined management and financial aspects the following results were obtained:

1) BUM Desa helathy categories as much as 84 BUM Desa or $38.2 \%$.

2) BUM Desa healthy enough categories as much as 30 BUM Desa or $13.6 \%$.

3) BUM Desa unhealthy categories as much as 84 BUM Desa or $38.2 \%$.
BUM Desa unactive categories as much as 22 BUM Desa or $10 \%$.

\section{Conclusion}

From the identification and analysis of data covering aspects of management and finance. financial issues of BUMDes in Blitardi Regency obtained the following results: (1) BUMDes in the Healthy category as many as 84 BUMDes or $38.2 \%$, (2) BUMDes in the Healthy Enough class as many as 30 BUMDes or $13.6 \%$, (3) BUMDes in the Unhealthy category 84 BUMDes or $38.2 \%$, (4) BUMDes inactive type are 22 BUMDes or $10 \%$.

\section{References}

Dewi K., S., A. 2014. Peranan Badan Usaha Milik Desa (Bumdes) Sebagai Upaya Dalam Meningkatkan Pendapatan Asli Desa (Pades) Serta Menumbuhkan Perekonomian Desa. Journal of Rural and Development. Volume V No. 1.

Ferdianto, B. (2016). Eksistensi Badan Usaha Milik Desa terhadap Peningkatan Pendapatan Asli Desa di Tiyuh Candra Kencana Kecamatan Tulang Bawang Tengah Kabupaten Tulang Bawang Barat.

Hadi, S. (2017). Pemeriksaan Keabsahan Data Penelitian Kualitatif Pada Skripsi. Jurnal Ilmu Pendidikan, 22(1).

Kustituanto, B., \& Badrudin, R. (1994). STATISTIKA 1: Deskriptif. Gunadarma.

Maulana, S. (2013). Tinjauan siyasah maliyah terhadap pengelolaan BUMDes dalam bidang pertambangan emas di Desa kertajaya Kecamatan Simpenan Kabupaten Sukabumi (Doctoral dissertation, UIN Sunan Gunung Djati Bandung).

Miles, M. B. Dan Huberman, A. Michael. 1992. Analisis Data Kualitatif.

Moleong, L.J. 2001. Metodologi Penelitian Kualitatif. Ban- dung: PT. Remaja Rosdakarya.

Nawawi, H. (2001). Metode Penelitian Bidang Sosial, Yogjakarta: Gajahmada University Press

Pebriyanti, S. (2020). Analisis Prinsip Pengelolaan Badan Usaha Milik Desa Dalam Meningkatkan Pendapatan Asli Desa Di Kecamatan Air Kumbang 
Kabupaten Banyuasin (Doctoral dissertation, Universitas Muhammadiyah Palembang).

Ridlwan, Z. (2014). Urgensi badan usaha milik desa (bumdes) dalam pembangun perekonomian desa. Jurnal Ilmu Hukum, 8(3), 424-440.

Sitepu, R. (2018). Analisis Proses Pembentukan dan Pengelolaan Badan Usaha Milik Desa (BUMDes) di Kecamatan Wampu Kabupaten Langkat.

Sururi, A., \& Mulyasih, R. (2017). Penguatan Kapasitas Masyarakat Melalui Inovasi Formulasi Kebijakan Perencanaan Pembangunan Partisipasif di Kecamatan Wanasalam Kabupaten Lebak. Wikrama Parahita: Jurnal Psengabdian Masyarakat, 1(1), 5-18. 